\title{
ANALISIS AGRIBISNIS SAPI POTONG DI KABUPATEN SIAK PROVINSI RIAU
}

\author{
Agribusiness Analysis of Cutting Cow in Siak Province District, Riau
}

\author{
Nurkhadijah, Syaiful Hadi, Evy Maharani \\ Program Studi Magister Agribisnis Fakultas Pertanian Universitas Riau, \\ Jl.Bina Widya No.30 Simpang Baru Tampan Pekanbaru \\ E-mail: Khadijahitw28@gmail.com 085228272095 \\ [Diterima: September 2016 ; Disetujui: Februari 2017]
}

\begin{abstract}
The study aimed to analyze the influence of each subsystem on the income of farmers and between each sub-system is itself on beef cattle farms in Siak. The study was conducted in 4 (four) districts in Siak District of Kerinci Kanan, Lubuk Dalam, Dayun and Koto Gasib using simple random sample selection method. Total sample in this study were 100 breeders. Data were analyzed by scoring and path analysis (path analysis). Path analysis results indicate that the up-stream subsystem to the farmer's income. The influence between the subsystem they are as follows: Subsystems supporting institutions affecting the entire subsystem of agribusiness, marketing subsystem affect up-stream subsystem, on-farm subsystem, and down-stream subsystem agribusiness, up-stream subsystem to the on-farm agribusiness, on-farm subsystem to down-stream agribusiness. The conclusion of the research indicated that the implementation of beef cattle subsystem agribusiness had an adequate index and give positive effect to the farmer's income.
\end{abstract}

Keywords: Agribusiness, Up-stream, On-farm, Down-stream, Marketing, Supporting institutions

\begin{abstract}
ABSTRAK
Penelitian ini bertujuan untuk menganalisis pengaruh masing-masing subsistem terhadap pendapatan peternak dan antara masing-masing subsistem itu sendiri terhadap peternakan sapi potong di Siak. Penelitian dilakukan di 4 (empat) Kabupaten di Kabupaten Siak, Kerinci Kanan, Lubuk Dalam, Dayun dan Koto Gasib menggunakan metode pemilihan sampel acak sederhana. Total sampel dalam penelitian ini adalah 100 peternak. Data dianalisis dengan penilaian dan analisis jalur (analisis jalur). Hasil analisis jalur menunjukkan bahwa subsistem hulu untuk pendapatan petani. pengaruh antara subsistem mereka adalah sebagai berikut: Subsistem lembaga pendukung yang mempengaruhi seluruh subsistem agribisnis; Subsistem pemasaran mempengaruhi subsistem hulu, subsistem pertanian dan subsistem hilir agribisnis. subsistem up-stream ke agribisnis on-farm, onfarm Subsistem ke agribisnis hilir. Kesimpulan penelitian menunjukkan bahwa penerapan agribisnis subsistem sapi potong memiliki indeks yang memadai dan berpengaruh positif terhadap pendapatan peternak.
\end{abstract}

Kata kunci: Agribisnis, Hulu, On-farm, hilir, Pemasaran, Lembaga pendukung

\section{PENDAHULUAN}

Pengembangan peternakan pada era globalisasi bertujuan untuk mewujudkan masyarakat yang sehat, produktif dan kreatif

melalui peternakan yang tangguh berbasis sumber daya lokal. Menurut Simatupang et al.,
(2004), dilihat dari segi peluang pasar pengembangan agribisnis peternakan memiliki prospek yang baik khususnya dalam memenuhi kebutuhan domestik yang semakin meningkat. Agribisnis adalah suatu usaha tani yang berorientasi komersial atau usaha bisnis pertanian dengan orientasi keuntungan. Salah satu upaya yang dapat ditempuh agar dapat meningkatkan pendapatan usahatani ádalah 
dengan penerapan konsep pengembangan sistem agribisnis terpadu, yaitu apabila sistem agribisnis yang terdiri dari subsistem hulu (sarana produksi), subsistem budidaya (produksi), subsistem pengolahan dan pemasaran dikembangkan secara terpadu dan selaras. Konsep dan pemikiran sistem dan usaha agribisnis juga telah dikembangkan. Permasalahan dalam agribisnis yang melibatkan rangkaian sistem yang panjang ini adalah lemahnya keterkaitan antar subsistem di dalam agribisnis, masing-masing pelaku dalam subsistem agribisnis (inside linkage, outside linkage) berkerja secara parsial.

Kabupaten siak sebagai salah satu dari 12 kabupaten/kota di Riau mempunyai potensi yang strategis untuk pengembangan agribisnis peternakan. Mata pencarian penduduk Kabupaten Siak sebagian besar adalah petani, yaitu sebanyak 62,173 jiwa $(38,48 \%)$ dari jumlah penduduk Siak 491,967 jiwa (BPS Kab. Siak, 2015). Mayoritas penduduk Siak yang berkerja sebagai petani dan peternak diharapkan mampu menerapkan sistem agribisnis untuk memperoleh nilai tambah pada usaha yang dijalankan sehingga dapat meningkatkan pendapatan. Kabupaten Siak memiliki potensi wilayah untuk lahan peternakan sebesar 108,204 Ha dengan kapasitas tampung ternak ruminansia kabupaten Siak 374.321,40 satuan ternak (ST) jumlah populasi ternak ruminansia kabupaten Siak pada tahun 2011 sebesar 12.510,09 ST dengan demikian, maka Kapasitas Tampung Ruminansia dan Kapasitas Penambahan Populasi Ternak Ruminansia (KPPTR) Kabupaten Siak diperkirakan masih ada peluang potensi untuk pengembangan peternakan sebesar 361.811,31 ST. Jumlah ini setara dengan 516.873 ekor sapi (Profil Dinas Peternakan Kabupaten Siak, 2012). Penelitian bertujuan untuk menganalisis pengaruh dari masing-masing subsistem itu sendiri terhadap pendapatan peternak dan antar masing-masing subsistem.

\section{METODE PENELITIAN}

Penelitian ini dilaksanakan di Kabupaten Siak diempat Kecamatan yaitu Kecamatan Kerinci Kanan, Lubuk Dalam, Dayun dan Koto Gasib. Penelitian dilakukan pada bulan Februari 2016. Metode yang digunakan dalam penelitian ini adalah metode simple random sampling atau pemilihan sampel acak sederhana terhadap responden peternak sapi potong dengan jumlah sampel 100 dari 1256 peternak. Teknik analisis data yang digunakan dalam penelitian ini adalah sebagai berikut.

a. Pendapatan (Y) bobot diukur berdasarkan besaran satuan rupiah yang diperoleh setelah dikurangi biaya operasional per periode pemeliharaan dan dianalisis secara kuantitatif dengan rumus:

$$
\begin{aligned}
& \mathrm{Y}=\mathrm{TR}-\mathrm{TC} \\
& \mathrm{C}=\mathrm{TVC}+\mathrm{TFC}
\end{aligned}
$$

$$
\begin{array}{ll}
\text { Keterangan : } \\
\pi \quad=\text { Pendapatan dari usaha ternak sapi } \\
& \text { potong }(\mathrm{Rp} / \text { tahun }) \\
\mathrm{TR} & =\text { Total penerimaan }(\mathrm{Rp} / \text { Tahun }) \\
\mathrm{TC} & =\text { Total biaya }(\mathrm{Rp} / \text { Tahun }) \\
\mathrm{TVC} & =\text { Total biaya variabel }(\mathrm{Rp} / \text { Tahun }) \\
\mathrm{TFC} & =\text { Total biaya tetap }(\mathrm{Rp} / \text { Tahun })
\end{array}
$$

Kemudian pendapatan dibuat skoring dengan menggunakan skala ordinal. Penentuan nilai skoring berdasarkan besaran pendapatan didasarkan pada perhitungan rasio pendapatan peternak terbesar dan terkecilnya.

b. Analisis jalur digunakan untuk menganalisis data yang diperoleh dari model yang disusun dan untuk mengetahui keterkaitan hubungan antara sejumlah variabel yang dapat diestimasi secara simultan. Selain itu variabel dependen pada satu hubungan yang sudah ada akan menjadi variabel independen pada hubungan selanjutnya. Berdasarkan Tabel 1 dicari model konstruksinya dengan mengggunakan path analisis pada aktivitas penerapan subsistem agribisnis terhadap pendapatan pada peternakan sapi potong di Kabupaten Siak, dengan hipotesisnya adalah:

H0 : Model kausalitas cocok dengan data empiris

HA : Model tidak cocok dengan data empiris

Model yang dikehendaki adalah nilai degrees of freedom (df)adalah positif karena apabila negatif atau nol maka tidak bisa di uji. Nilai chi-square diusahakan sekecil mungkin (mendekati nol) sehingga tidak signifikan dan nilai probabilitasnya tinggi $(p>0,05)$. Apabila ketiga hal tersebut dipenuhi maka dapat 
disimpulkan bahwa model tersebut cocok.

c. Analisis pengaruh dari masing-masing subsistem agribisnis terhadap pendapatan peternak dan antar masing-masing subsistem itu sendiri pada peternakan sapi potong di Kabupaten Siak digunakan uji $t$ dari konfirmatori faktor analisis (cfa) dengan menggunakan program Amos. Pengaruh dinyatakan signifikan apabila nilai probabilitasnya rendah $(\mathrm{p}<0,05)$ dan nilai CR>1,96. Gambar 1 diduga bahwa: penerapan sistem agribisnis yang terdiri dari (1) subsistem penyedia sarana produksi/hulu $\left(\mathrm{X}_{1}\right), \quad$ (2) subsistem budidaya/produksi ternak $\left(\mathrm{X}_{2}\right),(3)$ sub Isistem pengolahan dan pasca panen/hilir $\left(\mathrm{X}_{3}\right)$, (4) subsistem pemasaran $\left(\mathrm{X}_{4}\right)$ dan (5) subsistem penunjang $\left(\mathrm{X}_{5}\right)$ saling mempengaruhi dan berpengaruh terhadap pendapatan (Y) pada peternakan Sapi Potong di Kabupaten Siak. Berdasarkan gambar 1 subsistem hulu (sarana produksi) ternak berpengaruh terhadap sistem budidaya/produksi ternak dan subsistem budidaya/produksi ternak berpengaruh terhadap subsistem pascapanen. Subsistem pemasaran berpengaruh terhadap ketiga subsistem utama dan subsistem penunjang berpengaruh terhadap ketiga subsistem utama dan subsistem pemasaran.

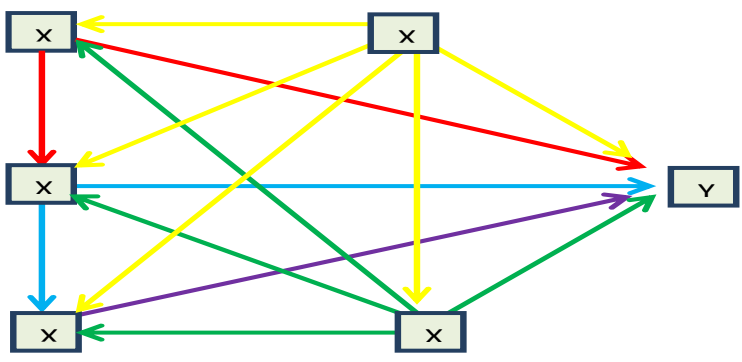

Gambar 1.Rancangan Model Konstruksi Aktivitas Sistem Agribisnis Sapi Potong di Kabupaten Siak

Tabel 1. Matrik Konsep Penjabaran Peubah

\begin{tabular}{|c|c|c|}
\hline Sistem Agribisnis & Peubah & Notasi \\
\hline \multirow{6}{*}{$\begin{array}{l}\text { 1. Subsistem penyedia sarana produksi ternak } \\
\text { (Hulu)/ } \mathrm{X}_{1}\end{array}$} & 1. Kandang & $\mathrm{X}_{11}$ \\
\hline & 2. Modal Produksi & $\mathrm{X}_{12}$ \\
\hline & 3. Induk & $\mathrm{X}_{13}$ \\
\hline & 4. Pakan & $\mathrm{X}_{14}$ \\
\hline & 5. Sarana prasana \&Peralatan & $\mathrm{X}_{15}$ \\
\hline & 6. Obat-Obatan & $\mathrm{X}_{16}$ \\
\hline \multirow{6}{*}{ 2. Subsistem Budidaya Ternak (on farm) $/ \mathrm{X}_{2}$} & 1. Tujuan Pemeliharaan & $\mathrm{X}_{21}$ \\
\hline & 2. Lokasi & $\mathrm{X}_{22}$ \\
\hline & 3. Pakan Ternak & $X_{23}$ \\
\hline & 4. Produksi Ternak & $\mathrm{X}_{24}$ \\
\hline & 5. Kesehatan Ternak & $\mathrm{X}_{25}$ \\
\hline & 6. Kesinambungan Usaha & $X_{26}$ \\
\hline \multirow{4}{*}{$\begin{array}{l}\text { 3. Subsistem Pengolahan dan Pasca Panen } \\
\text { (Hilir)/ } \mathrm{X}_{3}\end{array}$} & 1. Administrasi & $\mathrm{X}_{31}$ \\
\hline & 2. Pemanfaatan urin & $\mathrm{X}_{32}$ \\
\hline & 3. Pemanfaatan Feses & $X_{33}$ \\
\hline & 4. Kualitas produk & $\mathrm{X}_{34}$ \\
\hline \multirow{3}{*}{ 4. Subsistem Pemasaran/X $\mathrm{X}_{4}$} & 1. Pertukaran & $\mathrm{X}_{41}$ \\
\hline & 2. Sulpy Fisik & $\mathrm{X}_{42}$ \\
\hline & 3. Penunjang & $\mathrm{X}_{43}$ \\
\hline \multirow[t]{6}{*}{ 5. Subsistem Penunjang/ $\mathrm{X}_{5}$} & 1. Lembaga Keuangan & $\mathrm{X}_{51}$ \\
\hline & 2. Kelompok Ternak & $X_{52}$ \\
\hline & 3. Pasar Ternak & $\mathrm{X}_{53}$ \\
\hline & 4. Koperasi & $\mathrm{X}_{54}$ \\
\hline & 5. Lembaga Penyuluhan & $\mathrm{X}_{55}$ \\
\hline & 6. Poskeswan & $\mathrm{X}_{56}$ \\
\hline 6. Pendapatan & & $\mathrm{Y}$ \\
\hline
\end{tabular}




\section{HASIL DAN PEMBAHASAN}

\section{Biaya Produksi}

Biaya produksi usaha ternak sapi potong, peternak membutuhkan pengorbanan berupa variabel tidak tetap) untuk menghasilkan suatu biaya produksi (biaya variabel tetap dan biaya output (penambahan berat badan ternak sapi).

Tabel 2. Rata-rata Biaya Produksi pada peternakan sapi potong di Kabupaten Siak

\begin{tabular}{clr}
\hline No & \multicolumn{1}{c}{ Uraian (Rp/Tahun) } & Rata-Rata \\
\hline 1 & Biaya Variabel Tetap & 834.820 \\
A & Sewa lahan & 36.000 \\
B & Penyusutan Kandang & 678.700 \\
C & Penyusutan Peralatan & 120.120 \\
\hline 2 & Biaya Variabel Tidak Tetap & 8.440 .120 \\
\hline A & Bakalan & 3.595 .000 \\
B & Pakan Tambahan & 359.820 \\
C & Vaksin \& Obat & 406.700 \\
D & IB & 110.000 \\
E & Transportasi & 3.416 .700 \\
F & Tenaga Kerja & 234.000 \\
G & Listrik & 317.900 \\
\hline & $\quad$ Total Biaya Produksi & 9.274 .940 \\
\hline
\end{tabular}

Total biaya produksi pada usaha ternak dan biaya variabel tidak tetap dapat dilihat pada tabel 2. Biaya variabel tetap yang dikeluarkan dengan jumlah rata-rata $\mathrm{Rp}$ 834.820. Biaya variabel tetap yang tertinggi adalah biaya penyusutan kandang dengan rata-rata Rp.678.700 dan biaya terendah adalah sewa lahan. Bahan yang digunakan untuk pembuatan kandang sapi pada usaha ternak responden adalah beton, papan, kayu atau bambu untuk bagian dinding, seng atau rumbia untuk atap dan pada lantai ada yang menggunakan semen dan ada juga langsung ke tanah. Pemakaian beton ditujukan untuk menjaga keamanan ternak dari pencurian. Biaya penyusutan kandang yang dikeluarkan ditentukan oleh luas kandang yang dimiliki peternak dan juga umur ekonomis atau masa pakai kandang.

Biaya variabel tidak tetap yang dikeluarkan dapat dilihat pada tebel 2 dengan jumlah rata-rata biaya variabel tidak tetap sebesar Rp 8.420.120 per tahun. Dengan biaya tertinggi adalah baiya pembelian bakalan dengan rata-rata $\mathrm{Rp} 3.595 .000$ per tahun dan biaya terendah adalah biaya inseminasi Buatan (IB) rata-rata sebesar Rp 110.000 per tahun. Bahan pakan pada usaha ternak sapi responden menggunakan bahan pakan berupa hijauan yang diambil sendiri dengan cara diarit.
Total keseluruhan biaya produksi yang dikeluarkan oleh masing-masing peternak sebesar Rp 9.274.940 biaya yang dikeluarkan tidak banyak sebab peternak mengandalkan semua dari alam dalam pemberian pakan dengan cara menggembalakan di padang rumput dan pemeliharaan juga dilakukan diluar kandang atau digembalakan di padang rumput. Pada penelitian Eniza et al., (2006) rata-rata biaya produksi yang dikeluarkan sebesar Rp. 6.065.451 per tahun hal ini dikarenakan pada penelitian ini, biaya transportasi tidak dimasukkan kedalam biaya produksi.

\section{Penerimaan Usaha}

Penerimaan pada usaha ternak sapi meliputi penerimaan dari penjualan ternak sapi, penerimaan dari penjualan feses (pupuk kandang) dan penjualan urin tenak. Pada usaha ternak sapi di daerah penelitian dapat dilihat pada tabel 2 rata-rata penerimaan peternak dari usaha ternak sapi potong per responden per tahun dengan rataan 28.959.733 per tahun. Pada peternakan sapi potong di Kabupaten Siak penjualan dilakukan pada hari raya qurban pada saat harga tinggi jika peternak membutuhkan dana mereka memilih menjual sapi dara sehingga harganya lebih tinggi dan dijual pada peternak yang membutuhkan calon indukan. 
Nilai penerimaan terbesar dari penjualan ternak sapi dengan rata-rata Rp. 21.328.000 (74\%) penerimaan dari penjualan urin ternak rata-rata Rp.6.461.823 (22\%) dan penerimaan dari penjualan pupuk kandang rata-rata Rp.1.169.910 (4\%). Untuk Feses dan urin yang dihasikan peternak sebagian telah diolah sehingga penerimaan dari penjualan kotoran ternak mencapai Rp.7.631.733 yang lebih tinggi jika dibandingkan dengan Eniza dkk (2006) dengan total dengan rata-rata penerimaan hanya sebesar Rp. 9.713.857,14 dikarenakan penjualan ternak dilakukan pada usia muda biasanya terjadi karena peternak sangat memerlukan uang untuk keperluan perkawinan anaknya atau kebutuhan pendidikan dan hasil penjualan kotoran ternak Rp. 321.306 perbedaan ini disebabkan adanya perbedaan harga jual dan proses pengolahan sebelum penjual.

\section{Pendapatan rata-rata Peternak}

Pendapatan merupakan selisih antara penerimaan dengan total biaya produksi, sehingga besarnya pendapatan tergantung dari besarnya output yang dihasilkan. Pendapatan bersih usaha ternak merupakan hasil terhadap manajemen ternak dalam pelaksanaan usaha ternak sapi dari hasil analisis di daerah penelitian seperti yang terlihat pada tabel 3 Total penerimaan peternak selama satu tahun dari usaha ternak sapi sebesar Rp. 28.959.733 per tahun, sedangkan total biaya produksi peternak selama 1 (satu) tahun dengan rataan sebesar Rp. 9.274.940 per tahun sehingga diperoleh pendapatan bersih sebesar Rp. 19.684.793 per tahun. Pendapatan peternak sapi potong nilai skor yang diperoleh adalah 1,42 pada kriteria rendah. Hal ini dikarenakan pendapatan peternak dipengaruhi oleh faktor produksi ternak dalam hal ini adalah subsistem budidaya ternak (X2) yang merupakan subsistem yang memiliki skor terendah dibanding dengan subsitem agribisnis lainnya.

Tabel 3. Pendapatan Peternak sapi potong

\begin{tabular}{llr}
\hline No & \multicolumn{1}{c}{ Keterangan } & Jumlah (Rp) \\
\hline 1 & Penerimaan (Rp/Tahun) & 28.959 .733 \\
& Penjualan sapi (Rp/Tahun) & 21.328 .000 \\
& Penjualan Feses (Rp/Tahun) & 1.169 .910 \\
& Penjualan Urin (Rp/Tahun) & 6.461 .823 \\
\hline 2 & Total Biaya Produksi (Rp/Tahun) & 9.274 .940 \\
\hline & Biaya Variabel Tetap (Rp/Tahun) & 834.820 \\
& Biaya Variabel Tidak Tetap (Rp/Tahun) & 8.440 .120 \\
\hline 3 & Pendapatan (Rp/Tahun) & 19.684 .793 \\
\hline
\end{tabular}

\section{Ketepatan Model Agribisnis Peternakan Sapi Potong}

Analisis aktifitas menggambarkan hubungan antara variabel subsistem agribisnis terhadap penerapan agribisnis. Hasil penerapan agribisnis sapi potong diwujudkan dalam pendapatan peternak.

Model pengukuran untuk analisis faktor konfirmatori (Confirmatory Factor Analysis) dilakukan secara terpisah untuk konstrukkonstruk eksogen dan konstruk-konstruk endogen dimana prosedur analisis faktor konfirmatori mengacu pada Hair et.al (1995) yaitu: (1) analisis overall model fit, (2) analisis faktor loading dan (3) signifikansi faktor loading. Sebelum dilakukan analisa faktor konfirmatori terlebih dahulu akan dilakukan pengujian undimensionalitas variabel, baik eksogen dan endogen. Hair et al., (1995) mengatakan jika goodness-of-fit masing-masing tidak keluar jika diuji secara parsial maka variabel tersebut dapat disimpulkan fit. Hasil pengolahan dari Full Model SEM adalah sebagai berikut. 


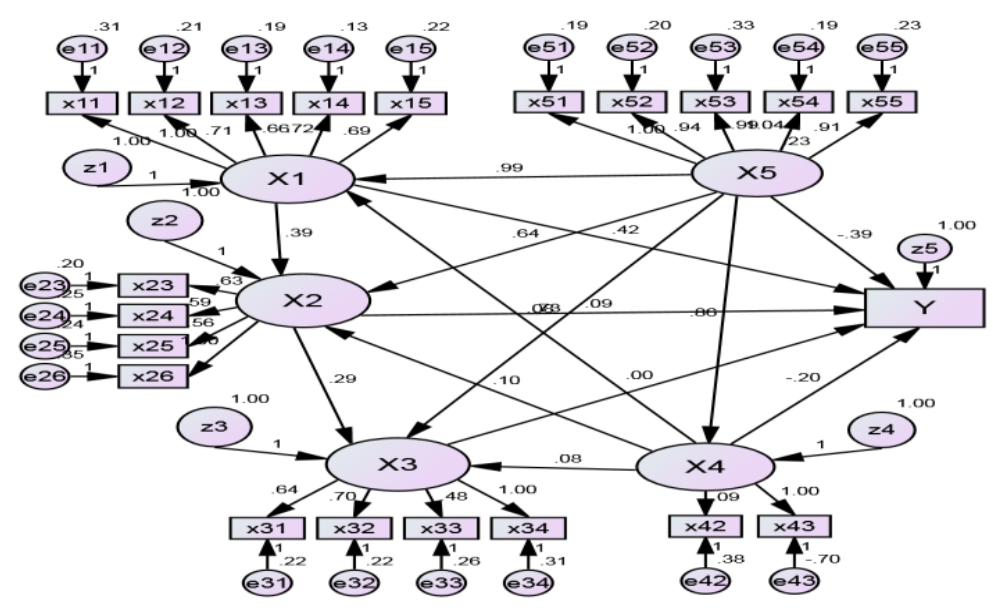

Gambar 2. Confirmatory Factor Analysis Structural Equation Model (SEM)

Keterangan:

$\mathrm{X}_{1} \quad$ Ketersediaan Sapronak

$\mathrm{X}_{2} \quad$ Budidaya ternak

$\mathrm{X}_{3} \quad$ Pengolahan \& pasca panen

$\mathrm{X}_{4} \quad$ Pemasaran

$\mathrm{X}_{5} \quad$ Lembaga Penunjang Agribisnis

Y Pendapatan

Tabel 4. Goodness of Fit Index

\begin{tabular}{lccc}
\hline \multicolumn{1}{c}{ Goodness of Fit Index } & Cut-off Value & Hasil Analisis & Evaluasi Model \\
\hline$\chi^{2}-$ Chi-square & $\mathrm{P}=5 \% \mathrm{df}=181$ & 782,388 & Sensitif terhadap sampel \\
& $(213,390)$ & & \\
Significance Probability & $\geq 0,05$ & 0,000 & Sensitif terhadap sampel \\
RMSEA & $\leq 0,08$ & 0,183 & Marginal Fit \\
GFI & $\geq 0,90$ & 0,619 & Marginal Fit \\
AGFI & $\geq 0,90$ & 0,513 & Marginal Fit \\
CMIN/DF & $\leq 2,00$ & 4,323 & Marginal Fit \\
TLI & $\geq 0,95$ & 0,377 & Marginal Fit \\
CFI & $\geq 0,95$ & 0,463 & Marginal Fit \\
\hline
\end{tabular}

Hasil pengujian terhadap nilai-nilai muatan faktor (loading faktor) untuk masingmasing indikator dapat dilihat pada tabel 4 . Tingkat signifikan antar subsistem agribisnis dari yang paling besar ke paling kecil dilihat dari hasil analisis adalah dari subsistem penunjang terhadap subsistem pemasaran, penyedia sarana produksi, subsistem penyedia sarana produksi terhadap subsistem produksi ternak, subsistem produksi ternak terhadap subsistem pengolahan dan pasca panen, subsistem lembaga penunjang ke subsistem pengolahan dan pasca panen dan subsistem budidaya ternak serta tingkat signifikan
Uji terhadap model menunjukkan bahwa model ini marginal fit terhadap data yang digunakan dalam penelitian meskipun tingkat probability sebesar 0,000 dan tingkat signifikansi terhadap Chi-Square model sebesar 782,388 tetapi nilai RMSEA, GFI, AGFI, CMIN/DF, TLI, dan CFI berada dalam rentang nilai yang diharapkan. Berdasarkan kriteria-kriteria goodness of fit pada tabel 4, maka dapat disimpulkan bahwa model struktural (SEM) yang dispesifikasi dalam penelitian ini telah fit dengan data. terkecil subsistem pemasaran terhadap subsistem budidaya tenak sedangkan terdapat dua yang tidak signifikan yaitu dari subsistem pemarasan terhadap pengolahan dan pasca panen dan subsistem penyedia sarana produksi ternak.

Untuk besarnya pengaruh antar subsistem agribinis pengaruh terbesar adalah dari subsistem lembaga penunjang memiliki pengaruh sebesar 99\% terhadap subsistem penyedia sarana produksi ternak. Pengaruh terbesar kedua adalah dari subsistem lembaga penunjang ke subsistem pemasaran dengan pengaruh $85 \%$. Selanjutnya secara berturut- 
turut pengaruh terbesar lainya adalah dari subsistem lembaga penunjang ke subsistem pemasaran (72\%), ke subsistem budidaya ternak (63\%). Pengaruh dari subsistem penyedia sarana produksi ternak terhadap subsistem budidaya ternak sebesar 39\%, pengaruh subsistem budidaya ternak terhadap subsistem pengolahan dan pasca panen sebesar $29 \%$ serta pengaruh dari subsistem pemasaran terhadap subsistem budidaya ternak sebesar 10 $\%$.

Pada subsistem produksi ternak tingkat signifikan terbesar adalah dari pakan ternak $\left(\mathrm{X}_{23}\right)$, produksi ternak $\left(\mathrm{X}_{24}\right)$ dan terendah kesehatan ternak $\left(\mathrm{X}_{25}\right)$ sedangkan untuk pengaruh dalam subsistem ini dapat dilihat pengaruh terbesar adalah pada pakan ternak $\left(\mathrm{X}_{23}\right)$ sebesar $63 \%$, produksi ternak $\left(\mathrm{X}_{24}\right)$ sebesar 58\% dan kesehatan ternak $\left(\mathrm{X}_{25}\right)$ sebesar $56 \%$. Pada subsistem pengolahan pasca panen dan sangat signifikan dan pengaruh yang terkuat adalah dari pemanfaatan feses $\left(\mathrm{X}_{32}\right)$ dengan pengaruh sebesar $69 \%$, administrasi $\left(\mathrm{X}_{31}\right)$ sebesar $63 \%$ dan pemanfaatan urin $\left(\mathrm{X}_{33}\right)$ sebesar $48 \%$. Pengaruh dan ringkat signifikan dalam sub pemasaran yang paling besar dilihat dari hasil analisis adalah pada suply fisik $\left(\mathrm{X}_{42}\right)$.

Tabel 5. Hasil Regresion Weights Full Model Penerapan Subsistem Agribisnis sapi potong

\begin{tabular}{|c|c|c|c|c|c|c|c|}
\hline & Penga & cuh & Estimate & S.E. & C.R. & $\mathrm{P}$ & \\
\hline $\mathrm{X}_{4}$ & $<--$ & $\mathrm{X}_{5}$ & .856 & .153 & 5.580 & $* * *$ & par_20 \\
\hline $\mathrm{X}_{1}$ & $<---$ & $\mathrm{X}_{5}$ & .990 & .274 & 3.608 & $* * *$ & par_22 \\
\hline $\mathrm{X}_{1}$ & $<---$ & $\mathrm{X}_{4}$ & .082 & .060 & 1.373 & .170 & par_23 \\
\hline $\mathrm{X}_{2}$ & $<---$ & $\mathrm{X}_{1}$ & .393 & .116 & 3.394 & $* * *$ & par_16 \\
\hline $\mathrm{X}_{2}$ & $<---$ & $\mathrm{X}_{5}$ & .639 & .301 & 2.119 & .034 & par_21 \\
\hline $\mathrm{X}_{2}$ & $<---$ & $\mathrm{X}_{4}$ & .102 & .061 & 1.675 & .094 & par_24 \\
\hline $\mathrm{X}_{3}$ & $<---$ & $\mathrm{X}_{2}$ & .291 & .108 & 2.682 & .007 & par_17 \\
\hline $\mathrm{X}_{3}$ & $<---$ & $\mathrm{X}_{4}$ & .085 & .060 & 1.412 & .158 & par_18 \\
\hline $\mathrm{X}_{3}$ & $<---$ & $\mathrm{X}_{5}$ & .726 & .302 & 2.404 & .016 & par_29 \\
\hline $\mathrm{X}_{11}$ & $<---$ & $\mathrm{X}_{1}$ & 1.000 & & & & \\
\hline$X_{12}$ & $<---$ & $\mathrm{X}_{1}$ & .709 & .052 & 13.515 & $* * *$ & par_1 \\
\hline $\mathrm{X}_{13}$ & $<---$ & $\mathrm{X}_{1}$ & .656 & .050 & 13.244 & $* * *$ & par_2 \\
\hline $\mathrm{X}_{14}$ & $<---$ & $\mathrm{X}_{1}$ & .722 & .046 & 15.619 & $* * *$ & par_3 \\
\hline $\mathrm{X}_{15}$ & $<---$ & $\mathrm{X}_{1}$ & .688 & .052 & 13.175 & $* * *$ & par_4 \\
\hline $\mathrm{X}_{26}$ & $<---$ & $\mathrm{X}_{2}$ & 1.000 & & & & \\
\hline $\mathrm{X}_{25}$ & $<---$ & $\mathrm{X}_{2}$ & .560 & .050 & 11.238 & $* * *$ & par_5 \\
\hline $\mathrm{X}_{24}$ & $<---$ & $\mathrm{X}_{2}$ & .587 & .051 & 11.416 & $* * *$ & par_6 \\
\hline$X_{23}$ & $<---$ & $\mathrm{X}_{2}$ & .631 & .049 & 12.934 & $* * *$ & par_7 \\
\hline$X_{34}$ & $<---$ & $\mathrm{X}_{3}$ & 1.000 & & & & \\
\hline $\mathrm{X}_{33}$ & $<---$ & $\mathrm{X}_{3}$ & .484 & .050 & 9.659 & $* * *$ & par_8 \\
\hline $\mathrm{X}_{32}$ & $<---$ & $\mathrm{X}_{3}$ & 699 & .053 & 13.227 & $* * *$ & par_9 \\
\hline $\mathrm{X}_{31}$ & $<---$ & $\mathrm{X}_{3}$ & .639 & .051 & 12.556 & $* * *$ & par_10 \\
\hline$X_{43}$ & $<---$ & $\mathrm{X}_{4}$ & 1.000 & & & & \\
\hline$X_{42}$ & $<---$ & $\mathrm{X}_{4}$ & .092 & .033 & 2.752 & .006 & par_11 \\
\hline $\mathrm{X}_{51}$ & $<---$ & $\mathrm{X}_{5}$ & 1.000 & & & & \\
\hline$X_{52}$ & $<---$ & $\mathrm{X}_{5}$ & .939 & .144 & 6.520 & $* * *$ & par_12 \\
\hline$X_{53}$ & $<---$ & $\mathrm{X}_{5}$ & .991 & .169 & 5.871 & $* * *$ & par_13 \\
\hline $\mathrm{X}_{53}$ & $<---$ & $\mathrm{X}_{5}$ & 1.039 & .151 & 6.897 & $* * *$ & par_14 \\
\hline $\mathrm{X}_{55}$ & $<---$ & $\mathrm{X}_{5}$ & .906 & .146 & 6.218 & $* * *$ & par_15 \\
\hline
\end{tabular}

Keterangan:***) significant sangat nyata pada tingkat kepercayaan $5 \%$ 
Pada sub lembaga penunjang tingkat sifnifikan tertinggi adalah dari Koperasi $\left(\mathrm{X}_{54}\right)$, kelompok ternak $\left(\mathrm{X}_{52}\right)$, lembaga penyuluhan $\left(\mathrm{X}_{55}\right)$ dan pasar ternak $\left(\mathrm{X}_{53}\right)$ sedangkan untuk pengaruh yang terkuat dalam subsistem lembaga penunjang ini terhadap pasar termak $\left(\mathrm{X}_{53}\right)$ dengan pengaruh sebesar $99 \%$, kelompok ternak $\left(\mathrm{X}_{52}\right)$ dengan pengaruh sebesar $93 \%$ dan lembaga penyuluhan $\left(\mathrm{X}_{55}\right)$ dengan pengaruh sebesar $90 \%$.

Tabel 6. Hubungan antara Variabel Penerapan Subsistem Agribisnis sapi potong terhadap Pendapatan

\begin{tabular}{lccc}
\hline \multicolumn{1}{c}{ Variabel Subsistem Agribisnis } & Kode & Estimasi & CR \\
\hline Ketersediaan Sapronak & $\mathrm{Y} \leftarrow \mathrm{X}_{1}$ & 0,415 & 3,625 \\
Budidaya ternak & $\mathrm{Y} \leftarrow \mathrm{X}_{2}$ & 0,085 & 0,756 \\
Pengolahan \& pasca panen & $\mathrm{Y} \leftarrow \mathrm{X}_{3}$ & 0,003 & 0,027 \\
Pemasaran & $\mathrm{Y} \leftarrow \mathrm{X}_{4}$ & $-0,200$ & $-3,520$ \\
Lembaga Penunjang Agribisnis & $\mathrm{Y} \leftarrow \mathrm{X}_{5}$ & $-0,394$ & $-1,299$ \\
\hline
\end{tabular}

Tingkat signifikan antar subsistem agribisnis terhadap pendapatan yang terbesar adalah dari subsistem penyedia sarana produksi ternak $\left(\mathrm{X}_{1}\right)$ dengan pengaruh sebesar $41 \%$, subsistem pemasaran dan lembaga penunjang berpengaruh negatif terhadap pendapatan sedangkan untuk subsistem lainya tidak sinifikan dan tidak berpengaruh langsung terhadap pendapatan.

Setelah semua asumsi dapat dipenuhi, selanjutnya akan dilakukan pengujian hipotesis. Pengujian hipotesis dilakukan dengan melihat nilai CR dan nilai probabilitas (p) pada hasil Regresion Weights Full Modelon Weights Full Model sebagaimana ditunjukkan dalam tabel 5 dan 6 dibandingkan dengan batas statistik yang disyaratkan, yaitu nilai di atas 1,96 untuk nilai CR dan dibawah 0,05 untuk nilai p. Apabila hasil Regresion Weights Full Modelon Weights Full Model menunjukkan nilai yang memenuhi syarat tersebut, maka hipotesis penelitian akan diterima. Hasil Regresion Weights Full Model menunjukkan bahwa terdapat beberapa variabel yang berpengaruh siginifikan terhadap varibel lain yakni:

1. Subsistem lembaga penunjang berpengaruh secara positif dan signifikan terhadap subsistem pemasaran. Hal tersebut dapat diartikan bahwa semakin tinggi peranan subsistem penunjang maka semakin tinggi pula subsistem pemasaran. Subsistem lembaga penunjang agribisnis $\left(\mathrm{X}_{5}\right)$ berpengaruh terhadap subsistem pemasaran (X4) ketersediaan pasar hewan ataupun lembaga yang mendukung pemasaran ternak sangat dibutuhkan bagi peternak dalam proses pemasaran ternak, oleh karena itu adanya lembaga penunjang tersebut sangat berpengaruh atas kelancaran pemasaran ternak.

2. Subsistem penunjang berpengaruh secara positif dan signifikan terhadap subsistem penyedia produksi ternak $\left(\mathrm{X}_{1}\right)$. Hal tersebut dapat diartikan bahwa semakin tinggi peranan subsistem penunjang maka semakin tinggi pula subsistem penyedia produksi ternak $\left(\mathrm{X}_{1}\right)$.

3. Subsistem penyedia sarana produksi ternak berpengaruh secara positif dan signifikan terhadap subsistem budidaya ternak. Hal tersebut dapat diartikan bahwa semakin tinggi peranan subsistem penyedia sarana produksi ternak maka semakin tinggi pula subsistem budidaya ternak. Hal ini sangat logis mengingat suatu produksi akan berlangsung jika terdapat sarana produksi. Pada usaha ternak sapi potong ketersediaan sarana produksi yang diperlukan anatara lain induk, pakan, obat dan tenaga kerja. Adanya hambatan dari salah satu sarana produksi maka akan menghambat proses produksi. Hal ini sesuai dengan konsep usaha ternak induk anak, karena dalam usaha sapi potong khususnya induk anak ketersediaan induk/bibit menjadi sangat penting karena produk utama yang dihasilkan berupa anak sapi atau pedet dihasilkan dari induk. Sehingga induk sapi potong merupakan mesin produksi dimana hasil produksi nantinya dapat dijadikan indukan atau dijual dalam bentuk pedet. Hasil Regresion Weights Full Model ini sesuai dengan hasil distribusi frekuensi ketersediaan sarana produksi, dimana indikator ketersediaan induk sudah diterapkan dengan baik.

4. Subsistem pemasaran berpengaruh secara positif dan signifikan terhadap subsistem 
budidaya ternak. Hal tersebut dapat diartikan bahwa semakin tinggi peranan subsistem pemasaran maka semakin tinggi pula subsistem budidaya ternak.

5. Subsistem penunjang berpengaruh secara positif dan signifikan terhadap subsistem budidaya ternak. Hal tersebut dapat diartikan bahwa semakin tinggi peranan subsistempenunjang maka semakin tinggi pula subsistem budidaya ternak.

6. Subsistem budidaya ternak berpengaruh secara positif dan signifikan terhadap subsistem pengolahan dan pasca panen. Hal tersebut dapat diartikan bahwa semakin tinggi peranan subsistem budidaya ternak maka semakin tinggi pula subsistem pengolahan dan pasca panen.

7. Subsistem penunjang berpengaruh secara positif dan signifikan terhadap subsistem pengolahan dan pasca panen. Hal tersebut dapat diartikan bahwa semakin tinggi peranan subsistem penunjang maka semakin tinggi pula subsistem pengolahan dan pasca panen. Subsistem lembaga penunjang $\left(\mathrm{X}_{5}\right)$ berpengaruh terhadap pasca panen $\left(\mathrm{X}_{3}\right)$ lembaga penunjang agribisnis mempunyai peran terhadap subsistem pasca panen karena berkelanjutan pasca panen dan kelayakan harga jual banyak bersinggungan dengan lembaga penunjang agribisnis seperti permodalan berhubungan dengan lembaga keuangan dan juga koperasi, mutu dan tingkat komparatif produk dan juga kelayakan harga dapat dketahui dari kelompok ternak maupun gapoktan dan pasar hewan. Oleh karena itulah lembaga penunjang agribisnis berpengaruh terhadap subsistem pasca panen.

8. Subsistem penyedia sarana produksi ternak $\left(\mathrm{X}_{1}\right)$ berpengaruh secara positif dan signifikan terhadap pendapatan. Hal tersebut dapat diartikan bahwa semakin tinggi peranan subsistem budidaya ternak $\left(\mathrm{X}_{1}\right)$ maka semakin tinggi pula pendapatan.

9. Subsistem pemasaran tidak berpengaruh langsung pada subsistem penyedia sarana produksi $\left(\mathrm{X}_{1}\right)$ dikarenakan tingginya tingkat pemasaran ternak tidak menjamin dapat meningkatkan sarana produksi ternak peternak karena peterkan melakukan usahanya belum untuk skala bisnis sehingga hasil pemasaran usaha ternaknya digunakan untuk kebutuhan rumah tangga, namun dengan pemasaran yang mudah dan harga jual yang tinggi mampu memberikan motivasi peternak untuk meningkatkan usaha tenaknya.

10.Subsistem pemasaran tidak berpengaruh terhadap subsistem pengolahan dan pasca panen, hal ini juga disebabkan karena pemasaran ternak yang terjadi adalah penjualan ternak hidup belum dalam bentuk daging sehingga proses jual beli yang terjadi tidak akan memepengaruhi subsistem pengolahan dan pasca panen.

11.Subsistem budidaya ternak tidak berpengaruh terhadap pendapatan.

12.Subsistem pengolahan pasca panen tidak berpengaruh terhadap pendapatan.

13.Subsistem pemasaran tidak berpengaruh terhadap tingkat pendapatan.

14.Subsistem penunjangmemiliki pengaruh negatif terhadap pendapatan. Hal tersebut dapat diartikan bahwa semakin tinggi peranan subsistem penunjang maka semakin rendah tingkat pendapatan.

Berdasarkan hasil Regresion Weights Full Model dan uji hipotesis diketahui bahwa lembaga penunjang agribisnis berpengaruh terhadap subsistem agribisnis hulu yang menyangkut ketersediaan sarana produksi $\left(\mathrm{X}_{1}\right)$, subsistem budidaya ternak, subsistem pasca penan $\left(\mathrm{X}_{3}\right)$ dan subsistem pemasaran $\left(\mathrm{X}_{4}\right)$. Lembaga penunjang agribisnis ini bila dilihat dari eksitensinya adalah suatu sistem yang berada diluar kondisi internal peternak. Oleh karena itu lembaga pendukung agribisnis pada dasarnya merupakan variabel eksogen yang dibutuhkan peternak. Hal ini diketahui bahwa untuk menyediakan saran produksi peternak membutuhkan pihak lain yang berperan sebagai penyedia input faktor, demikian juga dalam pemasaran ternak, peternak tidak melakukan sendiri mekanisme jual beli ternak namun membutuhkan lembaga pemasaran seperti pedagang yang mendatangi peternak.

Hasil Regresion Weights Full Model juga menunjukkan bahwa subsistem yang berpengaruh terhadap pendapatan adalah subsistem penyedia sarana produksi $\left(\mathrm{X}_{1}\right)$. Dengan ketersedian sarana yang tercukupi secara tidak langsung akan mempengaruhi subsistem lainnya sehingga akan meningkatkan pendapatan petani seperti dapat kita lihat bahwa pada subsistem penyedia sarana produksi ternak 
ini meliputi kelayakan kandang dengan kandang yang nyaman maka ternak akan berproduksi dengan baik terlindung dari hujan dan panas terik matahari sehingga ternak tidak kehilangan banyak energi untuk hal tersebut dan energi itu dapat digunakan untuk produksi dan reproduksi ternak seperti pendapat Agrofilo dan Endang (2012) sebagaimana manusia ternak sapipunperlu mendapatkan tempat tinggal yang nyaman hal ini berkaitan dengan kesehatan dan optimalisasi produksinya. Kandang mempunyai fungsi yang penting antara lain: melindungi sapi dari cuaca /iklim; sebagai tempat melakukan kegiatan tatalaksana produksi dan reproduksi; sebagai tempat yang nyaman dan aman dari binatang buas maupun pencuri (Urip, 2006).

Modal juga terdapat pada subsistem ini dengan modal yang sesuai maka dapat digunakan untuk membeli indukan yang sehat karena ternak yang sehat dan baik berharga mahal sehingga diperlukan modal yang cukup diharapkan dengan dengan induk yang sehat tersebut mampu menghasilkan anakan yang baik juga tentu hal ini juga harus didukung dengan ketersediaan pakan dilapangan karena pakan merupakan faktor terbesar dalam usaha ini sekitar $70 \%$ biaya usaha ternak pada baiaya pakan. Begitu juga dengan peralatan dan obatobatan jika semua yang dibutuhkan untuk usaha ternak ini tersedia maka secara langsung sub penyedia sarana produksi ternak ini akan mempengaruhi subsistem budidaya dan subsistem budidaya mempengaruhi subsistem pengolahan dan pasca panen. Pengaruh antar subsistem ini sangat mendukung pengaruh subsistem penyedia sarana produksi terhadap pendapatan. Adapun besarnya pengaruh dari subsistem penyedia sarana produksi ternak terhadap subsistem budidaya ternak sebesar $39 \%$, pengaruh subsistem budidaya ternak terhadap subsistem pengolahan dan pasca panen sebesar 29\% serta pengaruh dari subsistem pemasaran terhadap subsistem budidaya ternak sebesar $10 \%$. Hasil penelitian tidak jauh berbeda dengan yang dilakukan oleh Edy (2010) yang meneliti analisis pengaruh penerapan sistem agribisnis terhadap pendapatan usaha ternak sapi potong rakyat di jawa tengah menyatakan bahwa secara serempak subsistem agribisnis dan perencanaan agribisnis berpengaruh nyata terhadap pendapatan peternak sapi potong, namun secara parsial hanya subsistem praproduksi dan subsistem jasa penunjang agribisnis yang berpengaruh nyata terhadap pendapatan peternak sapi potong rakyat dan hasil penelitian Enggar (2012), yang mengkaji tentang " agribisnis ayam potong lokal (ayam hibrida) di Kabupaten Batang" subsistem penyedia sarana produksi $\left(\mathrm{X}_{1}\right)$ dan subsistem pemasaran $\left(\mathrm{X}_{4}\right)$ berpengaruh signifikan terhadap $\mathrm{Y}$ (pendapatan) hal ini dikarenakan pemasaran ayam potong telah terbentuk dengan baik dari berbagai aspek.

Empat subsistem lainnya merupakan subsistem yang tidak secara langsung berpengaruh terhadap pendapatan karena hasil Regresion Weights Full Model subsistem ketersediaan sarana produksi $\left(\mathrm{X}_{1}\right)$ berpengaruh terhadap subsistem budidaya ternak $\left(\mathrm{X}_{2}\right)$ dan $\mathrm{X}_{2}$ berpengaruh terhadap pemasaran subsistem pasca panen. Hal ini berarti bahwa subsistem ketersediaan sarana produksi akan mempengaruhi proses produksi yang merupakan on farm usaha ternak dapat mempengaruhi populasi ternak dari hasil kelahiran anak sapi atau pedet. Selanjutnya dari kondisi on farm berpengaruh terhadap pasca panen, dimana dalam pasca panen terdapat indikator pemanfaatan feses dan urin yang akhirnya akan berpengaruh pada pendapatan. Kondisi inilah yang menyebabkan proses produksi dan pasca penen tidak langsung berpengaruh terhadap penerapan pendapatan.Sedangkan subsistem pemasaran dan lembaga penunjang tidak berpengaruh terhadap penerapan agribisnis karena kedua subsistem tersebut berada diluar usaha ternak yang tidak mempengaruhi produksi. Hal ini serupa dengan hasil penelitian Titik (2012), yang mengkaji tentang "analisis penerapan subsistem agribisnis usaha ternak sapi potong di Jawa Tengah". Hasil Analisis Critical Ratio $(C R)$ menunjukkan bahwa subsistem agribisnis hulu berpengaruh terhadap proses produksi; subsistem proses produksi berpengaruh terhadap subsistem agribisnis hilir; subsistem agribisnis hilir berpengaruh terhadap pendapatan peternak, subsistem pemasaran berpengaruh terhadap subsistem agribisnis hilir dan Lembaga penunjang agribisnis berpengaruh terhadap subsistem agribisnis hilir dan pemasaran.

Hasil estimasi paling besar adalah hubungan antara subsistem penyedia sarana 
produksi terhadap pendapatan. Dari hasil analisis penerapan subsistem agribisnis dan indeks penerapan agribisnis serta analisis path maka penerapan agribisnis usaha sapi potong secara bersama-sama dipengaruhi oleh subsistem penyedia sarana produksi, budidaya ternak, pasca panen dan pengolahan produk, pemasaran serta lembaga penunjang agribisnis pada usaha ternak sapi potong. Namun bila disimak dari analisis pengaruh masing-masing varabel terhadap pendapatan, maka hanya subsistem penyedia sarana produksi saja yang berpegaruh langsung terhadap pendapatan. Akhirnya peranan subsistem lain perlu dikembangkan untuk memperbaiki pendapatan peternakan. Pengembangan tekonologi pada subsistem budidaya ternak yang berkaitan dengan teknologi produksi adalah langkah perbaikan untuk kulaitas bibit ternak, penggunaan input faktor, pakan tambahan, peralatan, dukungan keterampilan bagi peternak untuk dapat mengelola agribisnis peternakan dan memperbaiki pendapatan peternak.

Hubungan antar subsistem tersebut tidak ada kedudukan yang tersubordinasi, hubungan antar subsistem merupakan hubungan kolegial, hubungan fungsional, koordinasi vertikal yang saling membutuhkan, saling mengutungkan dan saling memperkuat. Rendahnya peningkatan pendapatan dan kesejahteraan petani peternak selama ini, karena terlalu berorientasi kepada produksi dan produktivitas, kurang berorientasi kepada kebutuhan pasar dan hubungan sistem agribisnis, sehingga perolehan nilai tambah rendah. Sinergi antara perusahaan usahatani dengan perusahaan agribisnis lainnya kurang solid. Akibatnya, permintaan produk pertanian menjadi tidak jelas dan harganya cenderung kurang menguntungkan petani (Suparta, 2001).

\section{KESIMPULAN DAN SARAN}

\section{Kesimpulan}

Aktivitas penerapan subsistem agribisnis terhadap pendapatan pada peternakan sapi potong di Kabupaten Siak didapatkan hasil bahwa hanya subsistem penyedia sarana produksi yang berpengaruh terhadap pendapatan. Pengaruh antar subsistem sebagai berikut: Subsistem lembaga penunjang berpengaruh terhadap seluruh subsistem agribisnis. Subsistem pemasaran berpengaruh terhadap subsistem penyedia sarana produksi ternak, subsistem budidaya ternak dan subsistem pengolahan hasil dan pasca panen. Subsistem penyedia sarana produksi ternak berpengaruh terhadap subsistem budidaya ternak dan subsistem budidaya ternak berpengaruh terhadap subsistem pengolahan dan pasca panen.

\section{Saran}

Adanya pengaruh yang saling berkaitan antar subsistem di dalam agribisnis maka disarankan peningkatan pada subsistem penyedia sarana produksi ternak; peningkatan kelayakan kandang, ketersediaan indukan, pakan, sarana dan prasarana dan obat-obatan meningkatkan pendapatan peternak. Peningkatan kegiatan pada subsistem penyedia sarana produksi mempengaruhi subsistem lain yang saling berkaitan maka untuk itu subsistem budidaya ternak perlu adanya teknologi dalam memenuhi kebutuhan pakan, peningkatan produksi ternak dengan manajemen perkawinan. Pada subsistem pengolahan pasca panen melakukan pengolahan kotoran padat dan cair sehingga menjadi nilai tambah usaha tani dan pada subsistem pemasaran pentingnya peran serta pemerintah dalam pemasaran pupuk padat dan cair ke perusahaan sawit sehingga produksi pupuk bisa berkelanjutan dan meningkatkan pendapatan peternak.

\section{DAFTAR PUSTAKA}

Agrofilo dan Endang P. 2012. Sapi dari Hulu ke Hilir dan Info Mancanegara. Penebar Swadaya. Bogor.

Badan Pusat Statistik (BPS). 2015. Siak dalam Angka 2015. BPS Kabupaten Siak. Siak.

Dinas Pertanian, Peternakan dan Perikanan Kabupaten Siak.2012. Profil Peternakan. Pemerintah Kabupaten Siak. Siak.

Edy Prasetyo. 2010. Analisis Pengaruh Penerepan Sistem Agribisnis terhadap Pendapatan Usaha Ternak Sapi Potong di Jawa Tengah. Disertasi, Universitas Diponegoro. Semarang.

Eniza Saleh, Yunilas, dan Yanda Habib Sofyan. 2006. Analisis Pendapatan Peternak Sapi Potong di Kecamatan Hamparan Perak Kabupaten Deli Serdang. Jurnal 
Agribisnis Peternakan, Vol.2, No.1, April 2006.

Enggar Prasetyo. 2012. Agribisnis Ayam Potong Lokal (Ayam Hibrida) di Kabupaten Batang Provinsi Jawa Tengah. Tesis Magister Agribisnis Universitas Diponegoro, Semarang.

Hair J,F, et,al. 1995. Multivariate Data Analysis With Reading. Fourth Edition. Prentice Hall.New Jersey.

Simatupang, P,S, Nizwar dan P,U Hadi. 2004. Arah dan Kebijakan Pengembengan Agribisnis Peternakan di Indonesia, Makalah disampaikan pada Seminar Nasional: Komunikasi Hasil-hasil Penelitian Ternak dan Usaha Pengembangan Peternakan dalam Sistem Usaha Tani Lahan Kering. BPTP Nusa Tenggara Timur, Waingapu, $23 \quad-24$ Agustus 2004.

Suparta.N. 2001. .Perilaku Agribisnis dan Kebutuhan Penyuluhan Peternak Ayam Ras Pedaging, [Disertasi], Program Pascasarjana Institut Pertanian Bogor, Bogor.

Titik Ekowati.2012. Analisis Usaha Ternak Sapi Potong dan Optimalisasi Usaha Peternakan Berbasis Sistem Agribisnis di Jawa Tengah.Disertasi Program Pascasarjana Fakultas Pertanian, Universitas Gadjah Mada, Yogyakarta.

Urip Santoso. 2006. Cara Beternak Sapi Potong yang Sukses. Sinergi Pustaka Indonesia. Bandung. 